
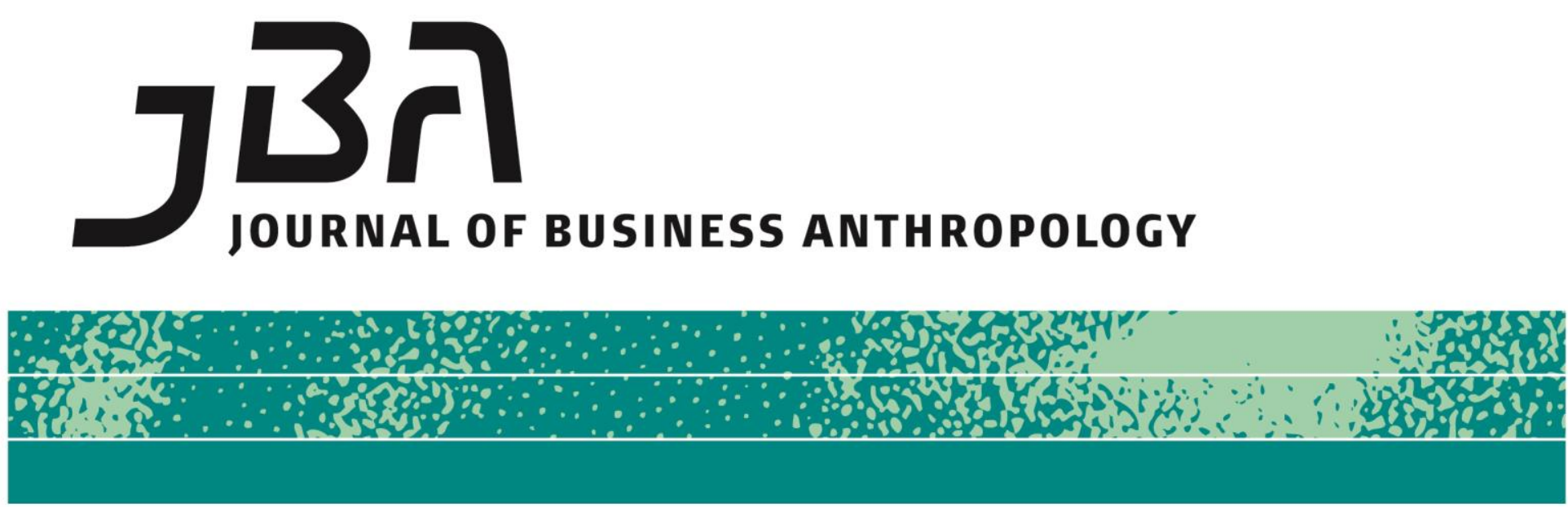

\title{
Playing with Morality: Business Ethics of a Professional Baseball Club in Taiwan
}

Jérôme Soldani

\begin{abstract}
Baseball is considered the national sport in Taiwan. Professional teams are owned by large local firms and are themselves small companies offering an archetypal model of society. Their practices are based on moral values around which their fans are unified. This is also a legacy of the social responsibility transferred to the Taiwanese firms by the former authoritarian regime (from the 1950s to the 1980s). Based on twelve months' fieldwork with a Taiwanese baseball club now owned by a holding company, this paper shows how the club is viewed as a firm structured around moral values and whose players are established as moral paragons. The model of a united, hierarchical family is highlighted by the original owners, a family firm which founded the club in 1984, and by the team's iconography. However, these methods of commodifying the team as a value-based family are faced with the realities of daily practices and the corruption scandals that regularly undermine the image of the Taiwanese professional league. The current company owner (from 2014) has tried to maintain this image of virtue, with some adjustments, in order to maintain the fans' identification with the club. The business ethics of the club is the outcome of these adjustments and negotiations between the owners, the players, and the fans.
\end{abstract}

Page 1 of 14

JBA Special Issue 3: 40-53, Spring 2016

(C) The Author(s) 2016 ISSN 2245-4217

www.cbs.dk/jba 


\section{Keywords}

Taiwan, Professional baseball, Business ethics, Moral values, Corruption, Fans

Many people wonder how the Brother Elephants' popularity has been so enduring and how its notoriety has remained so much stronger than that of the other clubs. There are, of course, several factors that account for this, such as its widely-held reputation as a "consistently victorious club," its strong tradition of strict discipline and its legendary games packed with twists and turns. However, the foremost reason is definitely the sense of determination and duty inherent in the way the club is run. To sum up, "Brother" is not a large consortium, but for twenty years it has wholeheartedly stirred a passion for baseball. This goodwill has earned the respect and support of many fans. This club has established a model of social responsibility among businesses in our country.

(Wang 2004: 6, translated from Chinese by the author)

This is how Wang Hueimin (璤), former sports reporter and High Commissioner of the Chinese Professional Baseball League (CPBL,

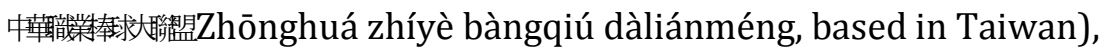
described the Brother Elephants baseball club in a brochure edited in 2004 , on the occasion of the club's twentieth anniversary. ${ }^{1}$ Brother Elephants is indisputably the most popular team in the league, and it is generally described as the best representative of the so-called "Taiwanese

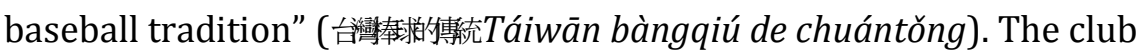
claims to adhere to this tradition and has always actively promoted this through its iconography and public relations.

The CPBL is a federation of large private companies, each of which owns a club that has itself been a limited liability company (Ltd.) since 2007. In order to keep fans loyal, and in accordance with the educational role given in Taiwan to both baseball-which benefits from the status of being a "national sport" (國求guóqiú)-and business, clubs depend on the promotion of moral values. This practice is not always sufficient to cope with supporters' demands for results, the players' professional imperatives, and the recurring corruption scandals linked to illegal gambling and fixed matches that have weakened the league since it was

\footnotetext{
1 This article is a revised and updated version of a paper published in the French journal Moussons (2013: 79-99).
} 
created in $1990 .^{2}$

What are these moral obligations, and how are they put into practice by the clubs? How are these norms negotiated between the directors who seek to impose them, employees who have to work with the daily constraints of their work, and customers (the fans) to whom the values are being promoted? These questions will be dealt with using field observations of the Brother Elephants club and its supporters, made during several stays adding up to twelve months of study between 2006 and 2014.

The point is not to make accusations of the owners of these clubs or to denounce any attempt at exploiting these moral values, but rather to analyse how these moral values are articulated and to what purpose they are used. The observations of this articulation of moral values and the negotiations between the different actors can help us understand Brother's business ethics. What is the role of the founding family, and from 2014 the holding company, that manages the club in fashioning an image of the club that is portrayed as a model of society? How is this reflected in the daily lives of the players? To what extent do the players obey the rules imposed, tacitly or otherwise, by the management? And what sanctions do they risk when disobeying these rules? What are the consequences of corruption scandals in a league that depends on strict adherence to moral guidelines? What is the relationship of the fans to the values promoted by clubs? All through this article, we will see that actors must choose between several competing value frameworks according to the context and to their own position.

\section{A family business}

The Brother Hotel baseball team was created in September 1984 as an amateur club. The club was renamed “Brother Elephants" (兄㒸象Xiōngdì xiàng) when it became professional in 1990 and one of the founding clubs of the CPBL along with Wei-chuan Dragons (味暗Wèiquán lóng), Mercuries Tigers (商虎Sānshāng hǔ) and Uni-president Lions (統獅Tǒngyī shī). The club became a limited liability company in 2007. It employs about eighty people, over half of whom are players; there are about ten coaches and physical trainers and almost twenty administrative staff (transportation, ticket sales, shop, administration, website, and so on). In a booklet produced in 2005 and for promoting the club to prospective sponsors, Brother claimed it had about 70,000 fans across the country: half of them were born in the 1980s; more than 40 per cent lived in the capital and its surroundings; and 45 per cent were women. Since the founding of the league, in 1990, until the present day, the Elephants have won the championship seven times: in 1992-1994, 2001-2003, and in

\footnotetext{
${ }^{2}$ On Taiwan baseball history, see Yu (2007) and Morris (2010).
} 
2010.

The history of Brother Elephants is closely linked with that of its founder's family, which has played a major role in the recent development of baseball in Taiwan-at least according to official biographies, which tend to go along the following lines:

The club was founded by Hung Teng-sheng (莇駦劵) considered “the father of professional baseball" in Taiwan for his crucial contribution to the creation of the league. He was the eldest of a family of five brothers and three sisters, born in Tainan in the south of the island. In the 1950s, his father, Hung Chao (潮期) started a factory producing sewing machines for export. Hung Chao was not a baseball player himself, but he supported the employees of his company who practiced the sport in their spare time. He created the team of Huanan (華南) named after his company, and encouraged his own children to practice the sport (Wang 2004: 9).

As a high-school student, Hung Teng-sheng became a member of the Huanan team. He then left to study for a business degree at National Taiwan University, the country's most prestigious school. He later started a company importing typewriters (and more recently, printers) from the Japanese firm Brother. In 1975, following governmental incentives to develop tourist facilities, he diversified his activities and, in partnership with his four brothers, opened a luxury hotel named Brother in the centre of the capital, Taipei. Hung Teng-sheng is still a baseball fan and plays regularly with his employees and family.

His hotel business having reached some sort of economic stability in the early 1980s, he created a baseball team in 1984, recruiting players after their graduation from universities or completion of military service. In 1985, he bought some land in Lungtan, in the county of Taoyuan, about 50 kilometres south of Taipei, and had a baseball stadium built there. It opened in 1986. It is often said that Hung gave up the opportunity to build a second hotel in order to achieve his dream of having his own stadium in which to play with his family and employees. The Lungtan stadium, which used to host professional league games, is still used today as a practice ground for professionals, as well as a playing field for the Hung family and the hotel employees who meet there every Tuesday afternoon, all year round except during the Spring Festival week. The five Hung brothers are all businessmen, baseball fans, and well-known sponsors in the Taiwanese sporting world, as is shown by the iconography of the club, which emphasizes their active involvement in the country's social life.

\section{"A role model for social responsibility"}

The club's logotype shows a remarkable range of symbols that have been built up over the years. Five letters " $\mathrm{H}$ " refer to the five Hung brothers, whose names start with an " $\mathrm{H}$ " in English transliteration. These five " $\mathrm{H}$ " letters are also associated with the five virtues, spelled out in English as: 
"Health, Honor, Harmony, Honesty, Humility" (Wang 2004: 157) or "5H." In 2013, the homepage of the club's English website points out that " $5 \mathrm{H}$ " is more than a symbol, it is a tradition and soul of the Brother Hotel and the Brother Elephant" (see illustration below). Each " $\mathrm{H}$ " is linked to two others in order to form a black and yellow plum blossom representing the team's colours. Plum blossoms, which bloom in winter and are resistant to low temperatures, symbolise resistance and perseverance, which echo the prevailing ideology of Taiwanese baseball, where players of all ages are expected to take part in repetitive and exhausting training sessions in all types of weather. The possibility of wresting victory from the opponent's hands until the very last second, according to the formal rules of the game, is also an incentive to extend efforts. Finally, the plum blossom refers to loyalty to the regime of the Republic of China, currently Taiwan's regime, for which it is an emblem (Destrebecq 2002: 206-207).

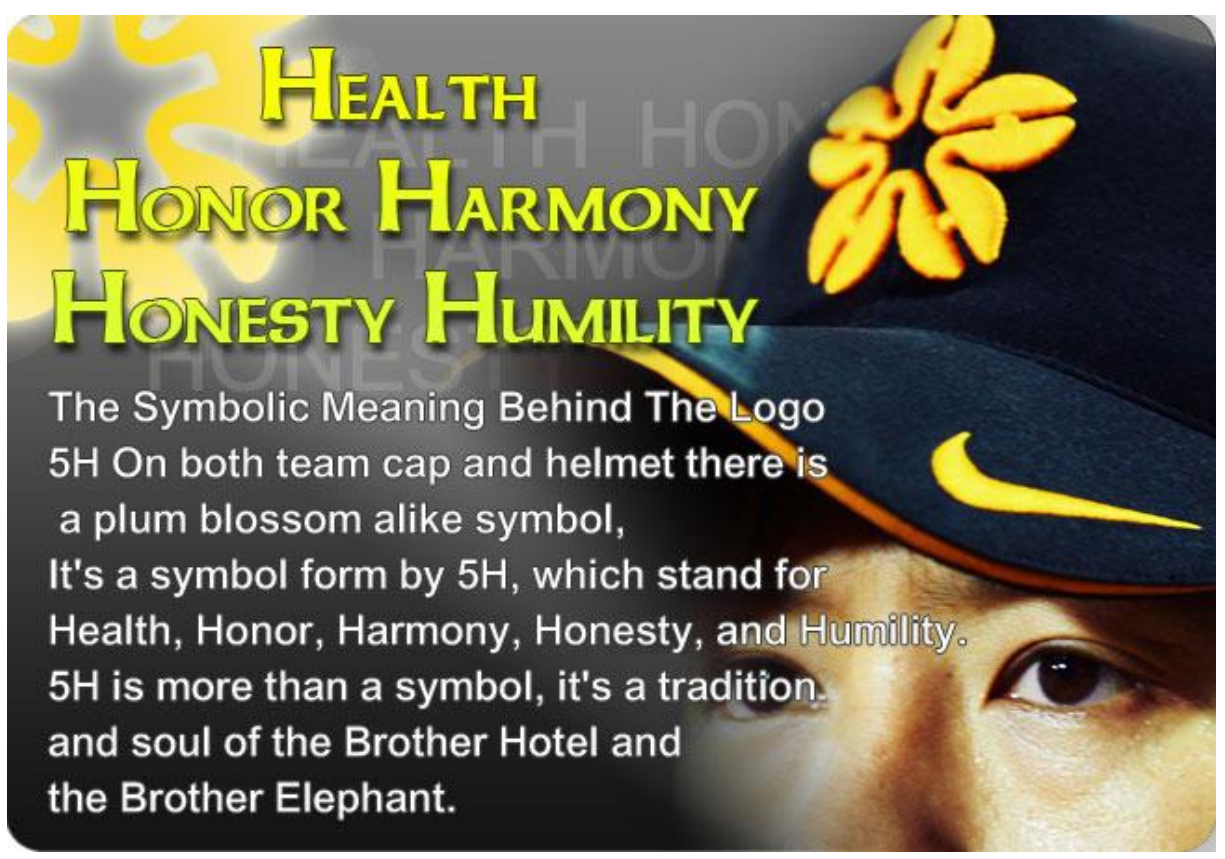

Figure 1: Home page of Brother Elephants English website in 2013 (http://www.brothers.com.tw/en/5H.php?cate=eh ) (accessed February 10, 2013).

Using the maxim of a few words as core values, such as those epitomised by the five " $\mathrm{H}$ " letters, is common practice in Taiwanese companies. In Southern Taiwan, companies often refer to the four principles: "diligence, frugality, honesty and loyalty" (勤食㚲言qín jiǎn chéng xìn) (Guiheux 2002: 198). Such exhortations have a mainly discursive and performative value. Their meaning is flexible and can be adjusted according to address and context. They should not be taken literally, and they have no absolute moral sense. Promoting values of peace, harmony, and understanding, which together position the company as a surrogate family and the boss as a surrogate father is also a way of rationalising 
practices which are, to a great extent, disconnected from such values (strict hierarchy; boundaries between leaders and employees, and so on) and arduous working conditions (difficult tasks, long hours, low, nonnegotiable wage levels, and so forth) (Guiheux 2002: 198-199).

The common use of maxims like these reveals an objective that most Taiwanese businessmen have in common: making their companies into social microcosms serving as role models for the whole population (Paix and Petit 1991: 30). This supervisory and educational objective was allocated to companies by the Chinese nationalist government, which retreated to Taiwan in 1949 after its defeat by the Communists on the mainland (Paix and Petit 1989: 20).

Such an order to set a good example is clearly stated by the baseball professional league, which is run directly by member companies. The order concerns primarily the players, whose contracts (Article 3) stipulate the following:

The player hereby agrees that: Professional baseball games are amongst the most popular forms of family entertainment in the Republic of China. Professional baseball players are often seen as role models by children and teenagers. Consequently, professional baseball should remain positive, pure, healthy and unspoilt. In order to fulfil this major social responsibility, players should not only work diligently, but also be honest, healthy and respectful of all provisions of the club and the league. Through good behaviour, fair play and sportsmanship, each player should become a role model for the citizens of the Republic of China.

(Chinese Professional Baseball League 2008: 73, translated from Chinese)

Thus Brother has built part of its reputation on displaying respect for family values. The back of the bus in which players commute almost daily, which serves as a true advertising medium, shows a cartoon family of elephants in a car-grandfather, father, mother and son. Marriage proposals, birthdays, or Mother's Day celebrations are regularly organised for fans in the stadium during games.

\section{Dictates, proscriptions and sanctions}

Few Taiwanese companies choose to own a baseball club because team maintenance is very expensive and the activity is deemed unprofitable. In twenty years (from 1984 to 2004), Brother has spent around 500 million Taiwan dollars (14 million euro) to maintain the Elephants baseball team (Wang 2004: 159). The income from selling tickets is generally insufficient to cover the cost of stadium rental. The rights to TV broadcasts are the main source of income for the clubs, with a maximum 
of 46 million Taiwan dollars (about 1.275 million euro) per year per team. The television channel Videoland (緯來Wěilái), which has been broadcasting baseball games from 1997, pays at the end of the season a sum fixed in advance with the professional league. The payment is increased or decreased according to the average viewing audience of each team. Until now, no club has achieved the full amount, for lack of sufficient audience. Brother, the team that attracts the most viewers, is regularly the least penalized team. Sponsors are generally large companies with which the club owner maintains close relations of “mutual aid" (人助rénzhù) (Guiheux 2002: 206-208). Budgetary balance is sought through merchandising: shirts, clothing, posters, fans, bracelets, key rings, and so on. Until the present, however, Brother is also the only club to have recorded profits after a season: that was in 2003, the year after it won a third consecutive championship title.

The club's advertising value, from which it draws most of its income (through sponsorships, merchandising, and so on), relies mainly on its public image. In addition to being a group of hard-working people, the club displays a whole range of significant educational values within Taiwanese society. It is eager to base its reputation on emblematic players or coaches with a career and all the exemplary virtues it advocates.

The main values extolled by the club are "perseverance" (振 héngxīn), "respect" (醺zūnzhòng) (for teammates, fans, opponents and their audience), and "politeness" (禮墽límào) as a manifestation of social hierarchy and conventions. At the end of each winning game, the Elephants face the bleachers of the opposite team and bow before they salute their own audience (Soldani 2011), and finally the field itself. The Brother team is the only team that acts out this ritual, as most teams salute only their own fans before leaving the field, whatever the outcome of the game.

“Discipline" (純聿jilù) and "respect for the rules" (諰巨guïjǔ) make up a series of restrictions which have been imposed on the players from their school years, such as refraining from drinking, smoking or chewing betel nut, and going out partying. These rules are openly applied and publicly spelt out, but in reality, they are discreetly broken in spite of financial sanctions-mostly in the form of deductions from wages-incurred by the offender. Several players smoke, even in the locker room before the game, drink alcohol, or do not deprive themselves of nightlife, even though they generally ensure that their behaviour remains discreet.

In private, these restrictions and accompanying sanctions are mocked by team members who deem them inept because of the discrepancy with their own reality. Rather than applying rules and regulations, which they claim to ignore, players refer to a list of chores regulating their daily lives. In June 2008 , these duties, handwritten on a board in their dormitory, consisted of cleaning baseballs, providing 
energy drinks, taking care of the ice bucket, pushing the ball cart, emptying the rubbish from the bus or the dormitory, washing clothes, turning lights off, and renting DVDs.

Acting as role models for their club does not exactly correspond to the purpose players have set themselves as part of the game: namely, training meticulously, playing a game seriously to ensure victory, and ensuring winning and coping with losing. The club's public image, defined by its social responsibility, therefore, does not necessarily correspond to the players' idea of their profession (Will 1991). ${ }^{3}$

\section{Fighting corruption}

Fines and deductions from wages are applied for errors or mistakes made on the field during a game. These sanctions can concern hesitant running or a slow hit. The club establishes the terms and conditions of such penalties. Rather than aiming at encouraging the players' performances, however, their real purpose is to discourage cheating. This cheating often takes place in the form of deals made with bookmakers connected with powerful local criminal organisations (Chin 2003).

To this day, however, these anti-cheating measures have appeared to have had no effect. Match-fixing scandals have occurred on a regular basis since the mid-1990s, each time involving a large number of players and coaches, politicians, and members of the police force. With the exception of the 2008 case involving mainly the D-media baseball club (Wang and Yu 2009), which in the final analysis belonged to the mafia, teams owners have never been involved in corruption scandals.

These cases are the reason most often given by the actors from the world of Taiwanese baseball (players, coaches, club management, journalists, spectators, etc.) to explain the decline in attendance that CPBL has been experiencing in recent years. Fans are refusing to follow a competition considered to be completely distorted. "Cheating" (放水 fàngshul) due to threats or greed as the media describe, is a breach of the moral contract between the professional players and their fans.

"Betting in professional baseball” (職奉簽賭zhíbàng qiāndǔ) is illegal and controlled by bookmakers linked to large criminal organizations in the country. It doesn't simply consist of ensuring a winner or loser; there is also betting on point spreads at the end of a game, or after a certain number of innings. To ensure the result, bookmakers seek the complicity of one or more players and coaches of at least one of the teams on the field. "Cheating" consists of throwing easy balls to the batter, willingly missing a catch, running slower, and so on. The cost of ensuring these services is eased by the extremely lucrative market of illegal betting,

${ }^{3}$ For a description of another professional baseball club in East Asia, see Kelly (2006) on Hanshin Tigers (阪神タイガース) in Japan. 
which is estimated by both judicial and journalistic sources at between two hundred and three hundred million Taiwan dollars bet by gamblers on each game (Huang 1997: 32).

A recent large-scale scandal, in 2009, concerned mainly the Elephants (Wang and Yu 2010; Soldani 2015). Following that, almost half the players and coaches were permanently barred from the league. Since then, each club has been placed under close supervision by the local prosecutor.

The club's president, for his part, urged fans to report any player's transgressions they might become aware of. These may range from smoking a cigarette on the street to mixing with suspicious people or having an extramarital affair. For this purpose, fans can fill in and submit a form found on the fans' page of the club's website. The president's call opened with the maxim: "Moral conduct distinguishes good from evil,

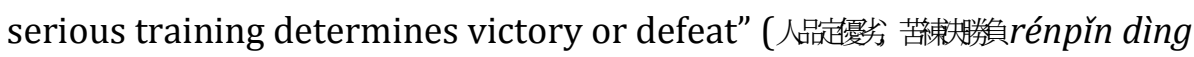
yōuliè, kǔliàn jué shèngfü ). ${ }^{4}$ However, this call to report on others, a legal and common practice in Taiwan (especially since the boom in modern technologies, social networks and 24-hour news channels), has never been followed up.

\section{"Brother Spirit" or "Elephants' Spirit"}

Brother is closely linked with its public, who are envisioned as the primary beneficiaries of the moral values extolled by the club. They are also the club's main customers, and the club's financial balance depends mainly on their numbers, their loyalty and how much they spend. The club therefore monitors fans' activities closely. The creation of any local fan group (後爱會hòuyuánhui) needs to be approved by the club. Elephants have support groups across the whole country. A company employee is responsible for relations with these groups and, before each game, brings them drums and flags, necessary to lead a Taiwanese fan group in the bleachers (Soldani 2011). ${ }^{5}$

Brother has built a rhetoric around this fraternity that also includes supporters. One of the main slogans of the club, "We are all brothers" playing on the name of the company in English, or in Mandarin, 四每之内皆

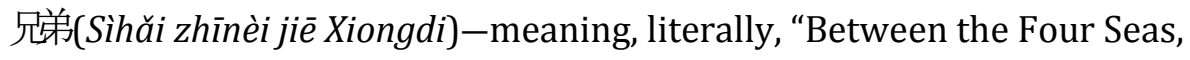
all Men are Brothers." This fraternal relationship, together with effort (even in suffering) and discipline, are values supposed to ensure success. They are celebrated in the club anthem, the "Song of the Brother

\footnotetext{
${ }^{4}$ http://www.brothers.com.tw/apply supervise.php?cate=pd (accessed June 20, 2012)

${ }^{5}$ The Taiwanese fans' cheering style has much in common with fans in Japanese bleachers (Kelly 1997; 2004).
} 
Elephants team" (兄弟象隊歌Xiongdi Xiang duìgē) ${ }^{6}$ :

Flies the team flag in the wind of victory

Masters of every moment

Disciplined, energetic, we are the Brother Elephants team

Scattered across the seas enthusiasm of brotherhood

That radiates the brilliance of our victories from the north to the south

In the wind and rain, under a blazing sun, nothing can undermine our confidence

Become one in brotherly love

Write the legend that belongs to us

Focus on our labor and our efforts

Our hopes and mutual aid

To accomplish together the mission that leads to triumph

By showing their adherence to common values through the phrase "Elephants Spirit" (争鬼Xiàng hún), the club's fans distinguish themselves from fans of other teams and from the company, which prefers referring to the "Brother Spirit" (兄首鬼Xīongdì hún) as a unique set of behaviour and attitudes closely associated with Taiwanese school baseball (Soldani 2012) ${ }^{7}$ and otherwise absent, or less important, among the other professional teams. This mistrust of the company sometimes goes along with (possibly strong) criticism of the management's choices and its expectations in terms of results, irrespective of moral considerations. Spectators can be well aware of the discrepancy between their heroes' real lives (even though they may not know all aspects) and the image provided by the club.

Their identity process is therefore more complex than a mere adherence to moral standards. It involves a sense of sociability and history, as well as personal choices. Depending on circumstances, spectators can read into an event or work out their own values according to their own criteria and priorities, as shown by the following example. In

\footnotetext{
${ }^{6}$ This song was written in March 2002 by Lin Kuo-jung (林或箖 and Chueh Chiahsing (關芳興). The lyrics are sometimes printed and distributed at the entrance to the stadium, just before a game, by members of the club's supporters group. The song was available for free listening on the website of the Brother Elephants: http://www.brothers.com.tw/player song.php?cate=pl (accessed February 10, 2013).

7 This is also the case in Japan, where high school baseball serves a similar function-especially the National High School Championship (全国高等学校野球 選手権大会 Zenkoku kōtō gakkō yakyū senshuken taikai), commonly named “Summer Kōshien” (夏の甲子園 Natsu no Kōshien), played annually in Nishinomiya city (near Ōsaka) from 1915 (Gordon 2006; Moeran 1984). Some authors compare a distinctly Japanese conception of baseball to its American counterpart, describing a "samurai style" characterized by the values of "effort" ( 努力doryoku) and “harmony" (和 wa) (Whiting 1977; 1989). However, the American anthropologist William W. Kelly points out that this opposition is more discursive than empirical (Kelly 1998; 2009).
} 
2006, one of the most popular Elephants players was dismissed from the team on suspicion of cheating (throwing a game) and corruption. A few fans tried to defend him, arguing that he had borrowed money from mobsters to rebuild his house following the 1999 earthquake. This affiliation with the player's “filial piety" (教颠iàoshùn)-helping his parents at any cost-could, in fans' eyes, cancel out an act of disloyalty.

\section{Elephants after Brother}

At the end of 2013, the club was sold to the Taiwanese holding company Chinatrust, because-according to the team's former owner-maintenance costs had become too high for the Hung family. Although Hung Jui-ho has never hidden his dismay over the corruption scandals, especially when his own players were involved, he never publicly mentioned other than financial reasons to justify the sale of the club. General conditions for players and coaches have hardly changed since then. Their salaries have been increased and their practices in training or on the field haven't changed. However, their environment has changed, mainly with a new dormitory, and there has been a partial replacement of the team's players, which caused quite a stir.

During the 2014 season, the new management did not wish to make radical changes to the club's image. They only tweaked things slightly so as not to provoke fierce opposition from the fans. The club's colours and hymn have been kept, as have been the tight connections with its history (the club's thirtieth anniversary was celebrated this year). The new owner's name has been added to the club's Chinese name. An "s" was added to the English name, turning "Brother" into "Brothers." However, the plum blossom, the symbol of the club, has been dropped, because it remains the symbol of the Brother Hotel.

The moral values of the club under the management of the Hung family have been kept and are still extolled. However, the club's new management relies on larger investments (for recruiting, construction of a new training field, and so on), and on the promotion of a more aggressive and dramatic playing style (the slogan for 2014 was "Strike hard!'); whereas the former management used to promote an organisation based on modest means (low wages, minimal recruitment, and so on) and a more reserved playing style, symbolising a more "traditional" (傳就chuántǒng) running of the club based on Japanese practices. As for fans, they ensure continuity through rhetoric, singing and artefacts from the previous management period, while still praising the "Elephants' spirit."

\section{Conclusion}

Family and moral values promoted by Brother are a model for the 
company's management, as well as for the whole society and the nation. Such values are both goods to sell and a way of exercising more effective control over employees, especially in the effort to fight corruption. However, the various actors (owners, players, fans) do not necessarily agree on how to define these values or on the priorities that should rule their activities.

In an attempt to enforce respect for these values, strict rules and regulations are formulated and applied to the letter. However, these constraints, like all constraints, are distorted, overlooked, or even totally ignored by those who value more practical needs in their daily lives, or who privately condemn what they view as the nonsensical obligations imposed by the club's owners. The confrontation of these values, which underlie each practice, with actors' practical strategies shows that they rely on several competing value frameworks underlying each practice, from which actors must choose according to the context and their own position. With this overlap of norms, there is no contradiction in a baseball club like Brother Elephants remaining a "model for social responsibility" despite the corruption scandals, because it is the players who are considered individually responsible for the situation, and the club management itself is never questioned in these cases.

If actors' beliefs (including those of the owners) cannot be questioned, club members' diverging practices must be taken into account, as well as the fact that spectators can put things into perspective. From an anthropological point of view, Brother's business ethics is not only the outcome of the former and current club owners endeavours to produce a commercial image, or a social model conforming to certain moral values. It is also, or even primarily, the result of constant negotiations between management and employees-mainly players and coaches-and between the club and its fans. Business ethics is not a set of standards; it is the result of competing practical agendas.

\section{References}

Brother Elephants Official Website, http://www.brothers.com.tw/ accessed February 10, 2013.

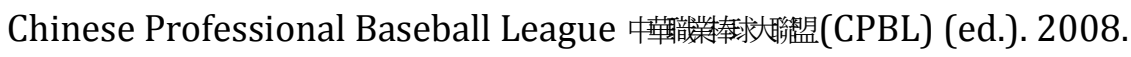

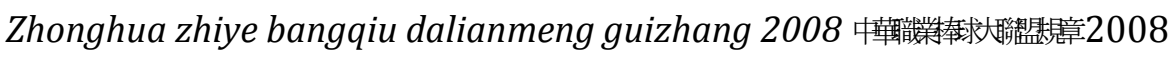
(Rules of the Chinese Professional Baseball League 2008). Taipei: CPBL.

Destrebecq, M.-A. 2002. Le symbolisme de la fleur de prunier dans la philosophie, la politique et l'esthétique chinoises des Song à nos jours. Études chinoises 21 (1\&2): 197-209.

Chin, K.-l. 2003. Heijin: organized crime, business and politics in Taiwan. New York: M.E. Sharpe. 
Gordon, D. 2006. Changing of the guard in high school baseball. In G. Gmelch (ed.), Baseball without Borders: The International Pastime. Lincoln: University of Nebraska Press, 3-21.

Guiheux, G. 2002. Les Grands Entrepreneurs privés à Taiwan. La main invisible de la prospérité. Paris: CNRS.

Huang, Y.-P. 黃英皮 1997. Taiwan zhibang heijin fengbao-Diyishou dujia

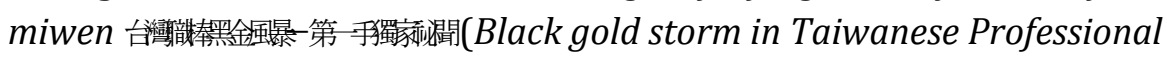
Baseball. Primary Sources). Taichung: Shuiyong.

Kelly, W. 1997. An anthropologist in the bleachers: cheering a Japanese baseball team. Japan Quarterly 44 (4): 66-79.

Kelly, W. 1998. Blood and guts in Japanese professional baseball. In S. Linhart and S. Frühstück (eds.), The Culture of Japan as Seen through its Leisure. Albany: State University of New York Press, 95-111.

Kelly, W. 2004. Sense and sensibility at the ballpark: what fans make of professional baseball in modern Japan. In W. Kelly (ed.), Fanning the Flames: Fans and Consumer in Contemporary Japan, Albany: State of New York University Press, 79-105.

Kelly, W. 2006. The Hanshin Tigers and Japanese professional baseball. In G. Gmelch (ed.), Baseball without Borders: The International Pastime. Lincoln: University of Nebraska Press, 65-88.

Kelly, W. 2009. Samurai baseball: the vicissitudes of a national sporting style. International Journal of the History of Sport 26 (3): 429-441.

Moeran, B. 1984. Individual, group, and seishin: Japan's internal cultural debate. Man (N.S.) 19: 252-266.

Moussons. 2013. Special Issue on Business Ethics in Southeast Asia, 21, https://moussons.revues.org/2071, accessed September 4, 2015.

Morris, A., 2010. Colonial project, national game: a history of baseball in Taiwan. Berkeley \& Los Angeles: University of California Press.

Paix, C. and M. Petit. 1989. Espace graphique et pratiques de pouvoir : philosophies d'entreprises à Taïwan, préceptes politiques à Singapour. Strates 4, http://strates.revuses.org/4262, accessed September 4, 2015.

Paix, C. and M. Petit. 1991. L'entreprise à Taiwan : le pouvoir des mots. Revue française de gestion 82: 28-44.

Soldani, J. 2011. Du côté des tribunes. Supporter une équipe de baseball professionnelle à Taïwan. Les Cahiers de l'idiotie 4: 65-116.

Soldani, J. 2012. L'ethnicité à l'épreuve du quotidien. Ethnographie d'une équipe de baseball lycéenne à Taïwan. Tsantsa 17: 96-105.

Soldani, J. 2015. Le cimetière des “Éléphants noirs'. Une étude anthropologique des matchs truqués relatifs aux paris dans le baseball taïwanais. Anthropologie et Sociétés 39(3): 217-235. 
Wang, H.-M. 王惠民 2004. Feixiang 20 nian. Xiongdi Xiang gan'en jishi

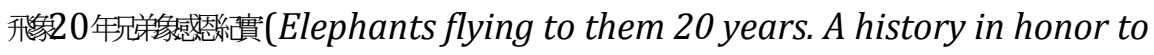
Brother Elephants). Taipei: Minshengbao.

Wang W.-S. 玟昇and J. Yu 盖帘韋 2009. «Taiwan zhiye bangqiu heian de

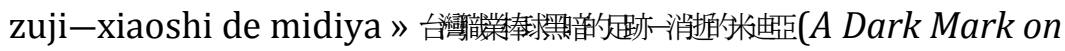
Professional Baseball in Taiwan-Dmedia vanished), 競趣䡃11 (2): 1-13.

Wang W.-S. 玟昇and J. Yu 搵发韋 2010. «Mishi de fang Kiang」: 2009 nian

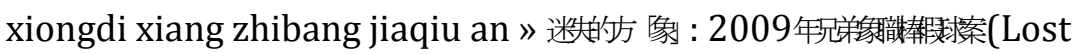
"Elephants": the Club of Brothers Elephants in the 2009 Scandal of Match Fixing in Professional Baseball), 競慟12 (1): 25-40.

Will, G. 1991. Men at Work: The Craft of Baseball. New York: Macmillan.

Whiting, R. 1977. The Chrysanthemum and the Bat: Baseball Samurai Style. New York: Avon/Discus Printings.

Whiting, R. 1989. You gotta have wa. New York: Vintage Books.

Yu, J. 2007. Playing in isolation: a history of baseball in Taiwan, Lincoln: University of Nebraska Press.

Jérôme Soldani is a cultural anthropologist, postdoctoral fellow at the Institute of Taiwan History (Academia Sinica, Taipei, Taiwan), research associate at the Taipei office of the French Center for Research on Contemporary China (CEFC, Taipei, Taiwan), the Lyon Institute of East Asian Studies (CNRS, Lyon, France) and the Institute of Mediterranean, European and comparative ethnology (CNRS, Aix-en-Provence, France). $\mathrm{He}$ is the co-editor, with Ghislaine Gallenga, of an anthology on business ethics (Archives contemporaines, 2015,

https://moussons.revues.org/2071) and a special issue on business ethics in Southeast Asia in the French Journal Moussons $(2013,21)$. He is the co-founder, in 2010, and the current president of the Francophone Association of Taiwan Studies (AFET, http://etudes-taiwanaises.fr/). He may be reached at jeromesoldani@hotmail.fr. 